\title{
QUESTIONING THE EXISTENCE OF THE INDONESIAN COMMISION STATE : AN IDEA OF RECONSTRUCTION
}

\author{
Putu Eva Ditayani Antari \\ Universitas Pendidikan Nasional \\ evaditayaniantari@undiknas.ac.id
}

\begin{abstract}
This research focuses on the phenomenon of the large number of state commissions in Indonesia, especially in the post-reform era. The State Commission, which was originally formed to carry out independent supervision of the government, was transformed into a State institution serving as an assistant to the government. The problems studied related to the State commission are the urgency of establishing a state commission and the position of the State commission in the Indonesian constitutional system. Through doctrinal legal research using a conceptual and comparative approach, it is known that state commissions are formed as a form of democracy, where there are independent institutions with the main task of supervising the three axes of state power (trias politica), especially in the sphere of government power. This state commission has a legal basis for the formation of various institutions through laws, government regulations, or presidential regulations so that not all state commissions have an equal position in the state administration. Furthermore, the incidental and responsive nature of the formation of state commissions often results in overlapping powers of state commissions. In order to resolve this, the idea is to make simplifications for the current State commission. The act of simplification is carried out by only maintaining a few State commissions that are capable of supporting the spirit of democracy in the State. Meanwhile, other commissions were merged into institutions of other countries. Furthermore, it is given legitimacy based on law to the State commission, so that it is not difficult to determine its position in the Indonesian constitutional system.
\end{abstract}

Keywords: Constitutional; Indonesian Commision State; Reconstruction;

\section{A. INTRODUCTION}

The state is a community organization to regulate life together with the aim of achieving common goals through a governance structure as the executor. Therefore, it can be understood Kranenburg and Logemann's reasons that the state is an organization of power. State power derives its source of legitimacy from an agreement made by individuals in the state to bind themselves and submit to the state government. The exercise of state power in order to achieve the common desired goal is then submitted to state institutions in the constitutional structure.

Montesqiueu through the Trias Politica theory states that the power of a country should be divided into 3 (three) branches of state power, 
namely legislative power, executive power and judicial power. ${ }^{1}$ The separation of powers within the state is also a feature of the rule of law teaching (Rechtstaat) put forward by Hans Kelsen. State power needs to be separated into branches of state power so that there is no centralization of power and the formation of arbitrary absolute power. Therefore, state power needs to be separated by operationalizing the principle of checks and balances in it. ${ }^{2}$

Checks and balances are commonly applied to countries that adhere to a separation of powers with the aim that the separate branches of state power will not cause excess monopoly in each of these branches of power. Each branch of power will be given the opportunity to supervise other branches of power so that they can balance each other. For example, the checks and balances that are applied in the United States through veto power in the formation of laws and regulations. The right of veto is the power that is owned by the President of the United States to reject the implementation of a law that has been passed by Congress. So that the law must be reviewed in the legislative body, especially with regard to matters that object to the president. Meanwhile, the implementation of checks and balances in Indonesia on similar matters is shown by the approval of the president in the formation of laws which fall under the authority of the House of Representatives (DPR). Based on this example, it is known that the application of checks and balances shows the involvement of one branch of power with the authority of another branch of power. However, the form of involvement of these branches of power is practiced differently.

The separate branches of state power have the aim of achieving the goals of the state and have the authority to carry out governmental duties. In order to achieve the goals of the state, the branches of state power are then carried out by state organs called state institutions. ${ }^{3}$ According to Ahmad Sukardja, state institutions were formed to carry out state functions, each state institution has a different position and function. ${ }^{4}$.

George Jellineck divides state institutions based on their position into unmittenbare organs and indirect state institutions (mittenbare organs). Direct state institutions are state institutions referred to by the constitution, namely state institutions that carry out the legislative, executive or judicial branches of power. Meanwhile, indirect state institutions are state institutions that depend on direct state institutions. State institutions are also directly referred to as main state institutions (main state's organs or primary constitutional organs). Meanwhile, indirect state institutions called

1 Efi Yulistyowati, Endah Pujiastuti, and Tri Mulyani, Penerapan Konsep Trias Politica Dalam Sistem Pemerintahan Republik Indonesia: Studi Komparatif Atas Undang-Undang Dasar Tahun 1945 Sebelum Dan Sesudah Amandemen, Jurnal Dinamika Sosial Budaya, Vol.18 No. 2, 2017, page.328;

2 Ahmad Yani, Sistem Pemerintahan Indonesia : Pendekatan Teori dan Konstitusi UndangUndang Dasar 1945, Jurnal Legislasi Indonesia, Vol.15 No.2, 2018, page.55-68;

3 Patrialis Akbar, Lembaga-Lembaga Negara Menurut UU NRI Tahun 1945, Sinar Grafika, Jakarta, 2013;

4 Ahmad Basarah, Kajian Teoritis Terhadap Auxiliary State'S Organ Dalam Struktur Ketatanegaraan Indonesia, Masalah-Masalah Hukum, Vol. 43 No. 1, 2014, page.1-8-8; 
auxiliary organs aim to strengthen the main state institutions in exercising their power. ${ }^{5}$

A paradigm shift in the existence of state institutions was put forward by Jimly Asshidiqqie who said that state institutions are no longer only related to the three branches of state power, but the relationship between the branches of power cannot touch one another. The three branches of power are equal and control one another in accordance with the principle of checks and balances. Apart from that, there are also other state institutions that are independent in nature to support the work of state institutions or are institutions that play a supervisory and balancing role. ${ }^{6}$

State institutions classified as supporting state institutions are referred to as state commissions. State commissions that have no work relationship with the government are independent state commissions because they are outside the branches of executive, judicial and legislative powers. However, this independent state commission can also be a mixture of the three canag of state power. If a state commission is formed as a branch of government and is tasked with supporting the performance of the government, it is called the executive state commission. Therefore it is stated that it tends not to be independent. ${ }^{7}$

The current institutional structure of the Indonesian state shows that in 2012 the number of state commissions in Indonesia was recorded at 93 (ninety three) commissions. ${ }^{8}$ Meanwhile, another source explained that in 2020 the number of state commissions which are also referred to as NonStructural Institutions (LNS) totaled 104 (one hundred and four) institutions, which have naming nomenclature starting from bodies, committees, authorities, institutions, work units and so on.

Based on these data, it is known that the number of Indonesian state commissions is very large with various functions, but there are also state commissions whose authorities seem to overlap with those of other state institutions and / or commission agencies. This also makes the existence of a state commission very potential to cause conflicts between state institutions and state commissions. Thus, it seems worth re-examining the urgency and basis for the formation of the state commission, and whether a simplification is possible.

Based on the explanation given in the background, in relation to state commissions in the Indonesian constitutional system, the following aim for this research is to know establishment of state commissions in addition to the main state institutions in the Indonesian constitutional system. Furthermore to analyze the position of the state commissions in the Indonesian constitutional system.

5 Achmad Roestandi, Mahkamah Konstitusi Dalam Tanya Jawab, Setjen dan Kepaniteraan MK, Jakarta, 2005;

6 Luthfi Widagdo Eddyono, Analisis Penyelesaian Sengketa Kewenangan Lembaga Negara Oleh Mahkamah Konstitusi, Jurnal Konstitusi, Vol.7 No.3, 2010, page.1-47;

7 Indriaswati Dyah Eddyono, Supriyadi Widodo Saptaningrum, Catatan Umum Atas Keberadaan Komisi Negara Di Indonesia, Jurnal Legislasi Indonesia, Vol.4 No.3, 2007, page.125;

8 Indonesia Jentera, Efektivitas Komisi Negara, Indonesia Jentera, School of Law, 2012, https://www.jentera.ac.id/publikasi/efektivitas-komisi-negara/. 


\section{B. RESEARCH METHODS}

This research is a normative legal research or often referred to as doctrinal legal research. It is called that because in this study it examines legal policies or legislation based on theoretical studies, but does not discuss its implementation. In this study, law is conceptualized as what is written in statutory regulations or law that is conceptualized as a rule or norm which is a benchmark for people's behavior towards what is considered appropriate. Therefore Soetandyo Wigyosubroto said that normative legal research is research on law that is conceptualized and developed on the basis of the doctrine adhered to by the author or developer. ${ }^{9}$

Likewise in this study the discussion of the existence of state commissions in Indonesia. The formation of a state commission adheres to the idea of putting democracy in the form of oversight of state power which is exercised by the main state institutions. However, in its implementation, the number of existing state commissions until 2020 is no longer unstoppable. In addition, the duties and powers of state commissions often overlap with other institutions. So that the urgency and existence of the state commission needs to be questioned in the Indonesian constitutional system.

In order to find the views of philosophical schools and conceptions about the position of state commissions in the Indonesian constitutional system, 3 (three) types of legal materials are used, namely primary legal materials, secondary legal materials, and tertiary legal materials. The primary legal materials used are UDNRI 1945 and other laws which form the basis for the formation of a state commission. Meanwhile, the secondary legal materials used are sourced from books and scientific journal articles that examine state institutions and their problems. Finally, tertiary legal materials are articles in print and electronic media which discuss state institutions in Indonesia.

All of this material was collected using the Mendeley reference application and is featured in a footnote excerpt on this study. These legal materials further show that there are different views regarding the application of the omnibus law in Indonesian law. In order to ensure the validity of the legal materials used, the author only uses legal materials from books or legal journals, both printed and online, which discuss state institutions.

Through this legal material, the problem of this research is presented with a qualitative analysis method. According to Soerjono Soekanto as quoted by Kamil Ardiansyah, qualitative analysis techniques are by examining theoretical matters concerning legal principles, legal conceptions, law, with views and doctrines of regulations and the legal system using secondary data, including: principles, rules, norms and legal rules contained in statutory regulations and other regulations, by studying books, laws and regulations and other documents that are closely related to research. ${ }^{10}$

9 Jonaedi Efendi and Johnny Ibrahim, Metode Penelitian Hukum Normatif Dan Empiris, 2nd ed. Prenada Media, Depok, 2018;

10 Mohammad Kamil Ardiansyah, Pembaruan Hukum oleh Mahkamah Agung dalam Mengisi Kekosongan Hukum Acara Perdata di Indonesia (Legal Reform by The Supreme Court of 


\section{OMNIBUS LAW AND INDONESIAN LEGISLATION PROCESS}

\section{The Establishment and Classification of State Commissions}

State institutions are an integral and inseparable part of the state's existence. The existence of this state institution is a necessity to fill and organize the country. The formation of state institutions is a manifestation of the mechanism for people's representation in running the government. ${ }^{11}$ Etymologically, the term state institution also has a variety of terminology, such as the Dutch which uses the term staat organen or in English it is called political institution. ${ }^{12}$

The term state institution is a translation of the term in English, namely political institution and the Dutch term staat organen. By definition state institutions are institutions established to carry out state functions. ${ }^{13}$ Saleh Adiwinata interpreted Fockema Andreae's view, giving the definition of an organ as a complement, namely a person or assembly consisting of people who are based on law or articles of association with the authority to express and realize the will of a legal entity. ${ }^{14}$

Hans Kelsen's view of state institutions has also been presented regarding the concept of the State Organ in his book General Theory of Law and State. Kelsen in the book conveyed a state institution as an organ, that is, anyone who carries out a function determined by a legal order (legal order). The organ is not always in the form of an organization or institution, more broadly an organ is defined as any position determined by law as long as its functions are norm-creating and / or norm-applying. ${ }^{15}$

Jimly then concluded that state organs from a limited perspective are state organs that are elected or appointed to occupy certain positions or functions. State organs carry out these positions or functions as the main profession or even legally have an exclusive character. Because of carrying out their positions and functions, state organs receive state rewards in the form of salaries. ${ }^{16}$

In another article, Jimly said that state institutions in Indonesia can be divided into 3 (three) groups. There are state institutions formed based on the order of the 1945 Constitution of the Republic of Indonesia (constitutionally entrusted power), state institutions formed based on statutory orders (legislatively entrusted power), as well as state

Indonesia Facing the Legal Vacuum in Civil Procedure Law), Jurnal IImiah Kebijakan Hukum, Vol.14, No.2, 2020, page.361-384;

11 Firmansyah Arifin, Lembaga Negara Dan Sengketa Kewenangan Antar Lembaga Negara, Konsorsium Reformasi Hukum Nasional (KRHN), Jakarta, 2005;

12 Arifin.

13 Moh. Kusnardi and Bintan Saragih, I/mu Negara, Gaya Media Pratama, Jakarta, 2000;

14 Lukman Hakim, Pelembagaan Komisi-Komisi Negara dalam Sistem Ketatanegaraan Republik Indonesia, Jurnal Konstitusi, Vol.II No.2, 2009, page.85-104;

15 Raisul Muttaqien, Teori Umum Tentang Hukum Dan Negara, Penerbit Nusamedia dan Penerbit Nuansa, Bandung, 2006;

16 Jimly Asshiddiqie, Perkembangan Dan Konsolidasi Lembaga Negara Pasca Reformasi, Sekretariat Jenderal dan Kepaniteraan Mahkamah Konstitusi RI, Jakarta, 2006; 
institutions established on the basis of orders from presidential decrees. ${ }^{17}$ State institutions whose authority is based on the constitution are the main state institutions and the existence of these institutions is a necessity in the state. Meanwhile, state institutions in the second and third groups are institutions known as state commissions. These institutions are not permanent but depend on the needs of the state. So that the possibility of the number of state commissions can increase or decrease.

Furthermore, state institutions are seen as having several levels or hierarchies of state institutions based on the degree of legal products that are the basis for their formation. For state institutions that are formed based on the constitution, these institutions are first-level state institutions such as the People's Representative Council (DPR), the Regional Representative Council (DPD), the People's Consultative Assembly (MPR), the Constitutional Court (MK), the Supreme Court (MA), Supreme Audit Agency (BPK) and the Judicial Commission. These institutions are mentioned and their authority is regulated in the constitution, hereinafter in more detail it is regulated in a law. The appointment of members of state institutions shall be determined by a Presidential decree and as the highest state administrative officials. ${ }^{18}$

Furthermore, second-level institutions are institutions established based on law, which means that the source of their authority comes from the legislators. In these state institutions, both the name and authority of the institution are given by law. Then the third state institutions are state institutions which derive their authority purely from the President as the head of government so that their formation comes entirely from the Presidential Decree (Presidentil Policy). This means that changes, or dissolution, depend solely on the President's policies. Finally, state institutions that are formed based on Ministerial Regulations, at the initiative of the minister as public officials based on the needs with regard to government and development tasks in the fields which are their responsibility, may be formed bodies, councils, institutions or committees it is not permanent and specific. ${ }^{19}$ In its development, the institutions that were present through non-constitutional arrangements became better known as state commissions.

State commissions that were present after the reform era in Indonesia have made the concept of trias politica which only limits state institutions to the scope of legislative, executive and judicial powers to be seen as irrelevant. The implementation of trias politica increasingly leads to a supervisory function and a balance between branches of state power. Therefore, each branch of state power and its implementing institution will often intersect with other branches of power. The increasing complexity of government has resulted in the emergence of various independent state institutions, so that state power is increasingly 
spread to various state institutions. ${ }^{20}$

The state commission according to Bunyamin Alamsyah and Uu Nurul Huda in theory stems from the will of the state to create a state institution whose members are drawn from non-state elements, given state authority, and financed by the state without having to become state employees. The state commission was formed from the idea of the state's previously strong desire when dealing with the community, being willing to provide opportunities for the public to supervise. So, even though the state is still strong, the government voluntarily provides flexibility to be monitored by the community so as to create vertical and horizontal accountability. The emergence of a state commission was intended to respond to the demands of the public for the creation of democratic principles in every administration of government through institutions that are accountable, independent, and trustworthy. ${ }^{21}$

The phenomenon of the emergence of various state commissions in the constitutional structure does not only occur in Indonesia. The presence of various state commissions generally occurs in a country that is undergoing a process of transition from an authoritarian government to a democratic government. The presence of the state commission can be in the form of an independent state commission or a state commission which is formed to assist in the implementation of governmental tasks. State commissions that are formed are also often not in accordance with the division of state power as indoctrinated in the teachings of trias politica, as a dynamic form of the paradigm of governance in the state. Samuel P. Huntington said that the birth of state commissions as new organs of power is a manifestation of the state's adaptation efforts to maintain stability in the state administration which tends to change in the process of democratization, so that it is expected to be able to realize state political order. ${ }^{22}$

Cornelis Lay then views that the birth of state commissions in Indonesia is influenced by several things, namely: ${ }^{23}$

a. the state's anxiety about the uncertainty and and negligence of the protection of marginalized individuals and groups, from the despotism of public officials and other citizens;

b. reflects the centrality of the state as a public authority, with a large public responsibility; and

c. is an evolutionary product that is incremental and complementary to the previously present organs of power, which is the result of selecting the idea of trias politica.

Almost similar to previous views, Firmansyah Arifin has the

20 Gunawan A. Tauda, Kedudukan Komisi Negara Independen dalam Struktur Ketatanegaraan Republik Indonesia, Pranata Hukum, Vol.6 No.2, 2011, page.171-82;

21 Bunyamin Alamsyah and Uu Nurul Huda, Politik Hukum Pelembagaan Komisi-Komisi Negara Dalam Sistem Ketatanegaraan Indonesia, Jurnal Hukum Dan Peradilan, Vol.2 No.1, 2013, page.85;

22 Samuel P. Huntington, Political Order in Changing Society, Yale University Press, New Haven and London, 1968;

23 Cornelis Lay, State Auxiliary, Jurnal Hukum Jentera, Vol.III No.12, 2006, page.14; 
perception that the formation of independent state commissions in the reform era was influenced by lack of credibility of existing institutions, unindependent, inability to carry out urgent, global influence, and pressure from international institutions. ${ }^{24}$ The presence of a state commission is solely due to 2 (two) reasons, namely related to the complexity of state tasks and strengthening the duties of state institutions. First, the presence of the state commission is a response to the increasingly complex state tasks that require sufficient independence for its operations. Second, state commissions are a form of empowerment efforts for existing state agency tasks by establishing new, more specific institutions. ${ }^{25}$

Of course, Hendra Nurtjahjo's opinion differs from the views of other legal experts who highlight the presence of the state commission as an excess of the failure of existing state institutions, as well as other cynical views. Meanwhile, Hendra Nurtjahjo described the reasons for the presence of a state commission as something that supports the development of the country towards a better direction, which is responsive to change and is more democratic. It's just that in this view it has not been described about the problems that will be faced related to its structural or non-structural position, the problem of funding sources originating from the state budget or being pursued by the state commission independently, the problem of non-civil servant or semi-civil service personnel.

Denny Indrayana said all fields of state seem to be competing to form a state commission, which was born based on a law. Furthermore, it was conveyed that the state commission in Indonesia was unclear due to the absence of a comprehensive constitutional concept about what and how a state commission should be. Finally, the state commission was only born as a reactive-responsive policy, but it was not a preventivesolution to the national problem. During the 1990s, South Africa and Thailand also transitioned from authoritarian rule. Both also experienced a period of booming state commissions. However, in contrast to Indonesia, the two countries designed their state commissions in a more planned and comprehensive manner. The South African Constitution regulates in detail the functions and duties of state commissions. Likewise in Thailand, the state commission has an honorable place in its constitution. ${ }^{26}$

Initially the state commission in the Indonesian constitutional system was presented as an independent state institution with several requirements, namely: ${ }^{27}$

a. The legal basis for its establishment clearly states the independence

24 Arifin, Lembaga Negara Dan Sengketa Kewenangan Antar Lembaga Negara., Konsorsium Reformasi Hukum Nasional (KRHN), Jakarta, 2005;

$25 \mathrm{~N}$ Hendra, Lembaga, Badan, dan Komisi Negara Independen (State Auxiliary Agencies) di Indonesia : Tinjauan Hukum Tata Negara, Jurnal Hukum Dan Pembangunan, Vol.3 No.JuliSeptember, 2005, page. 275

26 Denny Indrayana, Merevitalisasi Komisi Di Negeri Kampung Maling, Kompas, April 2005.;

27 Syukron Jazuly, Independent Agencies Dalam Struktur Ketatanegaraan Republik Indonesia, Supremasi Hukum, Vol.4 No.1, 2015; 
or independence of the relevant independent state commission in carrying out its duties and functions (normative requirements);

b. Independent, in the sense that it is free from the influence, will, or control of the executive branch of power;

c. Dismissal and appointment of commission members using a specific mechanism that is specially arranged, not solely based on the will of the President (political appointee);

d. The leadership of the commission is collective collegial, the number of members or commissioners is odd and decisions are made by a majority of votes;

e. The leadership of the commission is not controlled or the majority comes from certain political parties;

f. The term of office of the definitive commission leaders, expires concurrently, and can be re-appointed for the next one term; and

g. Membership of these state institutions is sometimes intended to maintain a balance of representation that is non-partisan in nature.

Against these conditions, it is not stated in more detail whether a state commission must fulfill all of these requirements or can only meet some of the criteria of the conditions. However, if viewed from the spirituality of forming a state commission in order to balance power, carry out supervision, and create democracy in the state, then some of the main conditions that a state commission should have, namely relating to the legitimacy of its formation, institutional independence, neutrality of the commission from the influence of political parties, transparency in selection of commissioners, and limitations on the terms of office as commissioners.

State commission which is recognized as a state institution must be formed based on a proper statutory regulation. A state commission should not be formed unilaterally based on the prerogative of the president alone (through a Presidential Regulation) but it is more appropriate if it is formed based on a law. Thus, there will not be any presumption in representative institutions or society that the formation of these institutions is only for the sake of sharing state power in the coalition group.

Regulations for the formation of state institutions through laws established by the House of Representatives and the President provide legal certainty related to the urgency of forming a state commission. Whereas a state commission is formed by means of an agreement between the President and the DPR through an academic study and discussion before its legitimacy is ratified in law.

The law which forms the juridical basis for the formation of the state commission must be able to guarantee the independence of the state commission from the influences of other powers. Apart from that, there are strict limitations regarding the powers that the state commission has, and does not conflict with other state institutions, especially with the main state institutions. Regulations regarding the selection mechanism, limitations on term of office, and accountability in 
the event of a violation by a member of the commissioner of a state commission must also be included in the constitution of the constitution.

The formation of state commissions in the Indonesian constitutional system can also be explained by John Alder's idea, namely that the existence of a state commission was triggered by the tendency factor in contemporary administrative theory to shift regulative and administrative tasks to become part of the duties of the state commission. Based on the characteristics described, John Alder then grouped the state commission into: ${ }^{28}$

a. Regulatory function, namely the state commission that is deliberately presented in the constitutional system to form regulations and provide assistance to the actions of private government institutions;

b. Advisory function, namely the state commission that functions as an advisor to provide considerations to the government regarding the policies implemented.

More detailed from Alder's view, Gerry Stoker divides the form of a state commission on the basis of classification on the source of funding sources to carry out the state commission, as well as the procedures for filling out and the origin of the state commission members. Based on these indicators, 6 (six) types of state commissions are stated, namely: ${ }^{29}$

a. Central government 'arm's-length' agency;

b. Local authority implementation agency;

c. Public / private partnership organization;

d. User organizations;

e. Inter-governmental forum; and

f. Joint boards.

State commissions that are present in Indonesia refer to the types of state commissions proposed by Stroke as state commissions as an extension of the government only. This is because state commissions refer to bodies established by statutory regulations at the central level, such as laws and / or presidential regulations. So that it will be referred to as a state commission when the institution is formed by the government at the national level. The consequence that arises is that state commission funding comes entirely from the state budget and its membership is classified as a civil servant.

Other institutions formed based on the legal product of regional governments are referred to as regional commissions, not state commissions. The regional commission has a source of funding from the regional budget in accordance with the principle of autonomy which is applied in regional government in Indonesia. Then an institution that is private in nature which consists of individuals or private legal entities cannot be classified as a state commission, but is called a NonGovernment Organization (NGO). NGO funding sources come from

28 John Alder, Constitutional and Administrative Law, The Macmillan Press LTD, London, 1989;

29 Gerry Stoker, The Politics of Local Government, 2nd Editio, The Macmillan Press LTD, London, 1991; 
mandatory and / or voluntary contributions from members, so it is not related to the state budget or regional budgets.

\section{The Dilemma of the Position of the Indonesian State Commissions}

State commissions that were presented in the post-reform Indonesian constitutional system had the idea of an independent institution capable of supervising the running of the government. This is consistent with the spirit of democracy, which was a form of authoritarian government during the New Order era. State commissions then exist through various legitimacy products of law and various powers. The state commission does not only have power in one branch of power according to trias politica, but the state commission can carry out different functions. There is a state commission whose job is to assist the government in exercising its authority, but there is also a state commission that acts as a supervisory agency. Ahmad Basarah also gave an example of the state commission which on the one hand is the regulator, but also punishes the judiciary mixed with the legislature. ${ }^{30}$ Thus, it is necessary to elaborate on the position of state commissions in the Indonesian constitutional system, as a form of legal certainty of their existence as an institution.

The presence of the state commission as a new independent and independent state institution is based on 5 (five) problem issues which then become the main basis for the formation of the state commission, namely those related to credibility, independence, adaptability, globalization, and the doctrine of international institutions. ${ }^{31}$ The presence of state commissions should be based on a strong foundation and a clear paradigm, so that their presence will be able to benefit the public interest and have a clear position in the Indonesian constitutional system.

Firmasyah Arifin revealed that the number of state commissions should not cause problems as long as their existence and foundation are able to adhere to the following principles: ${ }^{32}$

a. The principle of constitutionalism;

b. The principle of checks and balances;

c. The principle of integration;

d. The principle of expediency; and

e. The aim to fulfilling the welfare and basic rights of its citizens.

Tauda quoted Jimly Asshiddiqie's statement as saying that the presence of state commissions as an auxiliary institution is called state auxiliary organs or auxiliary institutions, which are state institutions that

30 Ahmad Basarah, Kajian Teoritis Terhadap Auxiliary State'S Organ Dalam Struktur Ketatanegaraan Indonesia, Masalah-Masalah Hukum, Vol. 43 No. 1, 2014, page.1-8-8;

31 Ni'matul Huda, Lembaga Negara Dalam Masa Transisi Demokrasi, UH Press, Yogyakarta, 2007;

32 Arifin, Lembaga Negara Dan Sengketa Kewenangan Antar Lembaga Negara., Konsorsium Reformasi Hukum Nasional (KRHN), Jakarta, 2005; 
are supportive in nature. The statement that a state institution or an independent state commission is an auxiliary state organ or is merely an auxiliary state is not entirely accurate, so it needs to be investigated further. Gunawan A. Tauda gave an example in reality several state commissions such as the Corruption Eradication Commission (KPK), the National Human Rights Commission (Komnas HAM), the Indonesian Broadcasting Commission (KPI) which is a state commission which is an important means to create a democratic rule of law and a state. demoration under the law. ${ }^{33}$

In contrast to the formation of state auxiliary institutions in other countries, independent state institutions in Indonesia are formed with a process that is not uniform. Some were established on the basis of statutory law (second group state institutions), while others were formed by order of a presidential decree (third group state institutions). ${ }^{34}$

State commissions as independent institutions are placed outside the executive, legislative and judicial branches of power. So it is considered that the state commission is a separate branch of power outside the government which is referred to as the fourth branch in the separation of state powers. However, there are also not a few legal experts who still classify state commissions under the executive branch of power. ${ }^{35}$ This is because the state commission has the duties and authorities related to efforts to assist the administration of government.

The position of the state commission as the fourth branch of power is based on the theory put forward by Bruce Ackerman regarding The New Separation of Power which applies to the government system in the United States. Independent institutions are placed in separate positions from the original branches of power, namely the executive, legislative and judicial branches. In addition, Yves Meny and Andrew Knapp also argued that the birth of a regulatory and supervisory agency is a new model related to governance, especially in the United States. The regulatory and supervisory institutions in the United States constitutional system are known as the Independent State Commission and are positioned in the fourth branch of power. ${ }^{36}$

Laying the state commission as the fourth branch of power in the state may not be entirely appropriate. Referring to the history of the formation of state commissions in Indonesia, the presence of state commissions as an auxiliary state institution is tasked with supporting the performance of the main state institutions. Therefore, the formation of a state commission is not regulated in the constitution. The presence of the state commission comes from various legal products either based on law

33 Gunawan A. Tauda, Kedudukan Komisi Negara Independen dalam Struktur Ketatanegaraan Republik Indonesia, Pranata Hukum, Vol.6 No.2, 2011, page.171-82;

34 Ni'matul Huda, Lembaga Negara Dalam Masa Transisi Demokrasi, UH Press, Yogyakarta, 2007;

35 Laurensius Arliman S, Kedudukan Komisi Perlindungan Anak Indonesia Sebagai State Auxiliary Bodies Dalam Sistem Hukum Ketatanegaraan Indonesia, Justitia et Pax, Vol.32 No. 2, 2017;

36 Syukron Jazuly, Independent Agencies Dalam Struktur Ketatanegaraan Republik Indonesia, Supremasi Hukum, Vol.4 No.1, 2015; 
or through a presidential regulation. Thus, if the position of the state commission is viewed from the legal basis of its formation as well as the duties and authorities it has, then the state commission is not equal but hierarchical with 3 (three) other branches of state power. The three branches of state power are exercised by state institutions whose positions are regulated in the constitution. Meanwhile, the state commission derives legitimacy from legal products that are hierarchically under the 1945 Constitution.

The sub-ordinative relationship between the state commission and the main state institutions regulated in the constitution was also conveyed by Tri Suhendra Arbani. The variety of juridical foundations for an institution makes the position of each institution different. Institutions whose formation relies on the constitution can be said to have a higher urgency than those formed based on law, because without the presence of the state it is deemed unable to operate. However, in practice this is not the case, such as the Judicial Commission established by the constitution, is it more important than Komnas HAM which is regulated in law. Meanwhile, the duties and powers of Komnas HAM to uphold human rights in a rule of law are also mandated by the constitution. ${ }^{37}$

The example presented by Arbani shows that the duties and authorities of the state commission which are formed are based solely on incidental issues related to problems faced by the state. Miranda Risang Ayu even said that from the point of view of the naming of state commissions, it often shows that state commissions have similar duties and functions, or at least carry out tasks and authorities in an interrelated scope of work. This raises the impression of duplication or overlapping of the powers of the state commission. ${ }^{38}$ So it will be difficult to maintain the existence of the state commission in the future. As a result, the position of the state commission in the Indonesian constitutional structure has become weak and constrained because it can lead to conflicts of authority.

The state commission which is an auxiliary state but exercises its authority independently appears to be running independently without coordination with the main state institutions whose performance must be supported. This is certainly not in accordance with the initial spirit of the formation of a state commission that is located outside the trias politica branch of power. It is recommended that the main state institutions and the auxiliary state institutions have a synergistic relationship and good communication patterns in carrying out their intersecting duties and authorities. The state commission should be aware of its position as an auxiliary state institution, and not be indifferent and neglectful of the coordination between state institutions which tends to trigger internal

37 Tri Suhendra Arbani, Analisis Yuridis Cabang Pemerintahan Keempat 'The Fourth Branch of Government' Dalam Struktur Ketatanegaraan Di Indonesia, Jurnal Hukum Ius Quia Iustum FH UII Jurnal Supremasi Hukum, Vol.5, No. 2, 2016, page.173.

38 Miranda Risang Ayu, Kedudukan Komisi Independen Sebagai State Auxiliary Institution Dan Relevansinya Dalam Struktur Ketatanegaraan Indonesia, Jurnal Konstitusi, Vol.I No.4, 2009, page.15-18. 
conflicts.

In order to solve several problems related to the position of the state commission in the Indonesian constitutional system, several legal experts have presented the idea of restructuring and simplifying the state commission. One of them is the view of Jhon M. Gaus regarding the number of state commissions in the United States and Britain. Gaus stated that the number of independent state commissions is not directly proportional to the effectiveness of the state commission's performance in providing services to the public. Therefore, Gaus proposed, this reorganization process could be carried out by intragation of several commissions, which have the same authority or service subject, combined into one commission. Or several commissions are sufficiently supervised by a coordinator / commission leader. This integration option is proposed by taking into account certain priorities of the purpose of forming a commission. ${ }^{39}$

Likewise in Indonesia, if restructuring and alignment are not carried out there are concerns that state commissions will merely strengthen the oligarchy of state power. That the state has a set of tools of power, which are fat and accommodate all problems, but at the level of implementation they are not able to work optimally. Overlaps and intersections of authority without coordination will result in state commissions making public services an object of struggle, and services not oriented towards the community.

The absence of restructuring and harmonization efforts can also lead to waste in the state budget. Not all of the state commissions currently have significant powers to fulfill the constitutional rights of citizens. Especially if the state commission's authority is limited to providing recommendations, without being equipped with any legal powers. Therefore, the existence of such a state commission will only waste the state budget which could have been allocated to improve services for the community.

Bunyamin Alamsyah and the Nurul Huda Law state that it is necessary to restructure and harmonize state commissions, so that each state commission is able to run synergistically, in carrying out its duties. 40 Harmonization efforts are carried out by evaluating the legal basis and changes in the powers of the state commission. The authority of the state commission which intersects with other state institutions must be exercised in coordination. Meanwhile, if the authority of the state commission overlaps with other state institutions, the existence of the state commission needs to be reviewed. Is the state commission maintained or is it merged with state institutions that have the same authority and be placed as sub-jurisdictions of state institutions. Therefore, based on the duties and authorities of state institutions, it can

39 Wahyudi Djafar, Komisi Negara: Antara 'Latah' Dan Keharusan Transisisional, ASASI ELSAM, 2009.

40 Bunyamin Alamsyah and Uu Nurul Huda, Politik Hukum Pelembagaan Komisi-Komisi Negara Dalam Sistem Ketatanegaraan Indonesia, Jurnal Hukum Dan Peradilan, Vol.2 No.1, 2013, page.85; 
be seen which state commissions are maintained in the administrative system and which can be eliminated.

State commissions which have an urgency for the fulfillment of people's rights have been retained, however, it is again divided which state commissions need to get a place to be regulated in the constitution, laws, or presidential regulations as the basis for their legitimacy. Furthermore, in regulating its legal basis, a state commission whose authority and role for the community is still considered weak needs to be strengthened in its scope and scope of work. This sorting is based on the level of significance and the public's need for the existence of these state commissions.

In relation to the selection of a state commission that deserves to be defended in the Indonesian constitutional system, according to Alamsyah and Huda, it refers to a state commission that supports the achievement of a rule of law and strengthens the implementation of separation of powers in Indonesia. Therefore, the 4 (four) criteria for maintaining the existence of a state commission are: ${ }^{41}$

a. A state commission that supports the implementation of a judicial system that is independent and with integrity, free from judicial mafia practices;

b. State commissions that support the protection of human rights;

c. State commission which guarantees the protection of press freedom; and

d. State commission which has the authority related to the holding of an honest and fair general election.

\section{CONCLUSION}

Based on the presentation of the ideas of state commissions and their simplification efforts, the formulation of the problem can be concluded that the formation of a state commission in Indonesia is intended as an auxiliary state institution that supports the implementation of democracy. The state commission is expected to be able to support the administration of government by the main state institutions which are regulated constitutionally.

The number of state commissions formed in post-reform Indonesia is considered to be too large. The current state commissions have various legal bases for formation, namely based on the 1945 Constitution, laws, or presidential regulations. The powers of several state commissions also have similarities and intersections with one another.

The idea of restructuring and harmonizing is a solution that is offered to solve the problem of the large number of existing state commissions and other impacts caused by it. Restructuring and harmonization are efforts to simplify state commissions by only maintaining state commissions that are deemed capable of supporting the realization of a rule of law and in accordance with the spirit of democracy that initiated the presence of the state commission.

41 Alamsyah and Huda. 


\section{E. ACKNOWLEDGMENTS}

Thank you to Mr. Tunggul Anzhari who inspired me to study issues concerning state commissions and write them as scientific articles. I also say thank you to my doctoral colleagues at Universitas Brawijaya, as well as the leadership of UNDIKNAS for their motivation to continue doing research and publication as a lecture.

\section{BIBLIOGRAPHY}

\section{Books:}

Akbar, Patrialis, 2013, Lembaga-Lembaga Negara Menurut UU NRI Tahun 1945, Jakarta;

Alder, John, 1989, Constitutional and Administrative Law, The Macmillan Press LTD, London;

Arifin, Firmansyah, 2005, Lembaga Negara Dan Sengketa Kewenangan Antar Lembaga Negara, Konsorsium Reformasi Hukum Nasional (KRHN), Jakarta;

Asshiddiqie, Jimly, 2006, Perkembangan Dan Konsolidasi Lembaga Negara Pasca Reformasi, Sekretariat Jenderal dan Kepaniteraan Mahkamah Konstitusi RI, Jakarta;

Efendi, Jonaedi, and Johnny Ibrahim, 2018, Metode Penelitian Hukum Normatif Dan Empiris. 2nd ed, Prenada Media, Depok;

Huda, Ni'matul, 2007, Lembaga Negara Dalam Masa Transisi Demokrasi UH Press, Yogyakarta;

Huntington, Samuel P, 1968, Political Order in Changing Society, New Haven and Yale University Press, London;

Indrayana, Denny, 2005, Merevitalisasi Komisi Di Negeri Kampung Maling, Kompas, Jakarta;

Kusnardi, Moh., and Bintan Saragih, 2000, Ilmu Negara, Gaya Media Pratama, Jakarta;

Muttaqien, Raisul, 2006, Teori Umum Tentang Hukum Dan Negara, Penerbit Nusamedia dan Penerbit Nuansa, Bandung;

Roestandi, Achmad, 2005, Mahkamah Konstitusi Dalam Tanya Jawab, Setjen dan Kepaniteraan MK, Jakarta;

Stoker, Gerry, 1991, The Politics of Local Government. 2nd Edition, The Macmillan Press LTD, London;

\section{Journals:}

Alamsyah, Bunyamin, and Uu Nurul Huda, Politik Hukum Pelembagaan KomisiKomisi Negara Dalam Sistem Ketatanegaraan Indonesia." Jurnal Hukum Dan Peradilan, Vol.2 No.1, 2013 
Ardiansyah, Mohammad Kamil, Pembaruan Hukum Oleh Mahkamah Agung Dalam Mengisi Kekosongan Hukum Acara Perdata Di Indonesia (Legal Reform by The Supreme Court of Indonesia Facing the Legal Vacuum in Civil Procedure Law), Jurnal IImiah Kebijakan Hukum, Vol.14, No.2, 2020;

Arliman S, Laurensius, Kedudukan Komisi Perlindungan Anak Indonesia Sebagai State Auxiliary Bodies Dalam Sistem Hukum Ketatanegaraan Indonesia, Justitia et Pax, Vol.32 No.2, 2017;

Ayu, Miranda Risang, Kedudukan Komisi Independen Sebagai State Auxiliary Institution Dan Relevansinya Dalam Struktur Ketatanegaraan Indonesia. Jurnal Konstitusi, Vol.I No.4, 2009;

Basarah, Ahmad, Kajian Teoritis Terhadap Auxiliary State'S Organ Dalam Struktur Ketatanegaraan Indonesia, Masalah-Masalah Hukum, Vol.43 No.1, 2014;

Eddyono, Supriyadi Widodo Saptaningrum, Indriaswati Dyah, Catatan Umum Atas Keberadaan Komisi Negara Di Indonesia, Jurnal Legislasi Indonesia Vol.4, No.3, 2007;

Eddyono, Luthfi Widagdo, Analisis Penyelesaian Sengketa Kewenangan Lembaga Negara Oleh Mahkamah Konstitusi, Jurnal Konstitusi Vol.7 No.3, 2010;

Hakim, Lukman, Pelembagaan Komisi-Komisi Negara Dalam Sistem Ketatanegaraan Republik Indonesia, Jurnal Konstitusi, Vol.II No. 2, 2009;

Hendra, N, Lembaga, Badan, Dan Komisi Negara Independen (State Auxiliary Agencies) Di Indonesia: Tin.Jauan Hukum Tat A Negara, Jurnal Hukum Dan Pembangunan, Vol.3 No. Juli-September,2005;

Jazuly, Syukron, Independent Agencies Dalam Struktur Ketatanegaraan Republik Indonesia, Supremasi Hukum, Vol.4 No.1, 2015;

Lay, Cornelis, State Auxiliary, Jurnal Hukum Jentera, Vol.III No.12, 2006;

Tauda, Gunawan A., Kedudukan Komisi Negara Independen Dalam Struktur Ketatanegaraan Republik Indonesia, Pranata Hukum, Vol.6 No.2, 2011;

Tri Suhendra Arbani, Analisis Yuridis Cabang Pemerintahan Keempat 'The Fourth Branch of Government' Dalam Struktur Ketatanegaraan Di Indonesia, Jurnal Hukum Ius Quia Iustum FH UII Jurnal Supremasi Hukum, Vol.5 No.2, 2016;

Yani, Ahmad, Sistem Pemerintahan Indonesia: Pendekatan Teori Dan Konstitusi Undang-Undang Dasar 1945, Jurnal Legislasi Indonesia, Vol.15 No.2, 2018;

Yulistyowati, Efi, Endah Pujiastuti, and Tri Mulyani, Penerapan Konsep Trias Politica Dalam Sistem Pemerintahan Republik Indonesia: Studi Komparatif Atas Undang-Undang Dasar Tahun 1945 Sebelum Dan Sesudah Amandemen, Jurnal Dinamika Sosial Budaya, Vol.18 
No.2, 2017;

\section{Internet:}

Indonesia Jentera, Efektivitas Komisi Negara, Indonesia Jentera, School of Law, Last modified 2012. Accessed March 29, 2021. https://www.jentera.ac.id/publikasi/efektivitas-komisi-negara/;

Djafar, Wahyudi, Komisi Negara: Antara 'Latah' Dan Keharusan Transisisional, ASASI ELSAM, 2009. Accessed March 31, 2021. https://wahyudidjafar.files.wordpress.com/2010/01/komisinegara_antara-latah-dan-keharusan-transisional2.pdf. 